\title{
NOTE
}

\section{Impact of iceberg scouring on polar benthic habitats}

\author{
Julian Gutt*, Andreas Starmans, Gerhard Dieckmann
}

Alfred Wegener Institute for Polar and Marine Research, Columbusstraße, D-27568 Bremerhaven, Germany

\begin{abstract}
In situ photographs and videos demonstrate that iceberg grounding in both polar regions causes considerable damage to benthic communities. Sessile organisms are eradicated and pioneer species begin to grow in high abundances on the devastated substratum. A preliminary quantitative analysis shows that the sea floor in the Antarctic and Arctic areas of investigation is disturbed by icebergs statistically once every 230 and $53 \mathrm{yr}$, respectively. Due to the extreme slow growth of many species, particularly in Antarctica, areas frequently disturbed in this manner are likely to be characterised by a continuous natural fluctuation between destruction and recovery. Increased perturbation by iceberg groundings through predicted global warming will result in considerable impairment of this environment.
\end{abstract}

KEY WORDS: Antarctic Arctic Benthos I Iceberg scouring Global warming

Recently, the calving of Antarctic ice shelves has been discussed with respect to global warming (Doake \& Vaughan 1991, Gammie 1995) and the consequences of resulting iceberg scouring on the structure of the sea bed have been documented for both polar areas (Lien et al. 1989, Woodworth-Lynas et al. 1991). Yet the possible effect on the underlying benthic communities, other than by small growlers, has not yet been broached. Our analysis shows for the first time the impact of iceberg grounding and scouring on the Antarctic and Arctic benthos. The results provide an idea of the benthic system's resilience to such natural catastrophic events. They also enable us to assess consequences of a possible atmospheric warming, to which both polar ecosystems are considered particularly sensitive (Houghton et al. 1990).

Material and methods. The sea floor was videotaped by a remotely operated vehicle and photographed in the Antarctic Weddell and Lazarev Seas $\left(47^{\circ} \mathrm{W}\right.$ to $12^{\circ} \mathrm{E}, 69^{\circ} \mathrm{S}$ to $\left.79^{\circ} \mathrm{S}\right)$ and the Amundsen and Bellingshausen Seas $\left(120^{\circ} \mathrm{W}\right.$ to $65^{\circ} \mathrm{W}, 67^{\circ} \mathrm{S}$ to $73^{\circ} \mathrm{S}$; Fig. 1a) as well as off northeast Greenland $\left(77^{\circ} \mathrm{N}\right.$ to
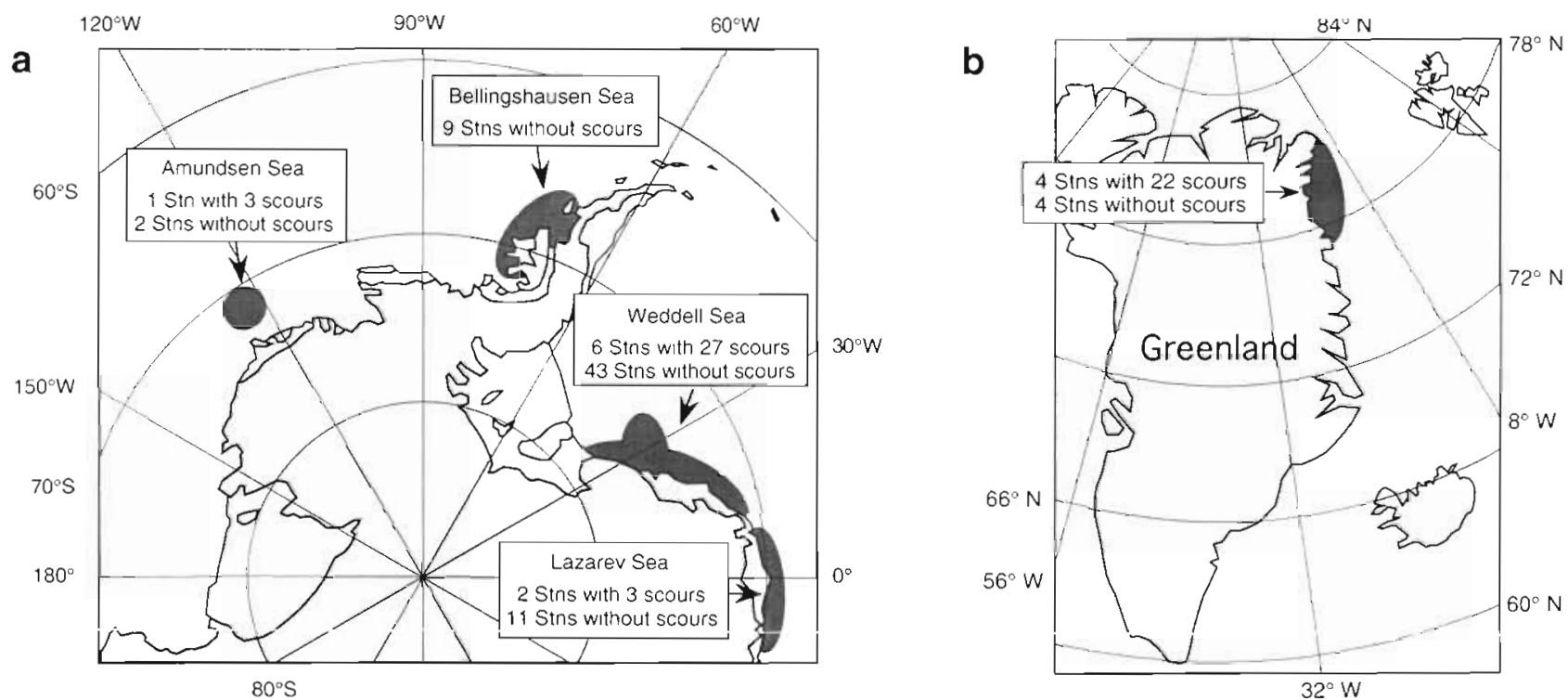

Fig. 1. Areas of investigation: (a) Antarctic, (b) off northeast Greenland

-E-mail: jgutt@awi-bremerhaven.de 

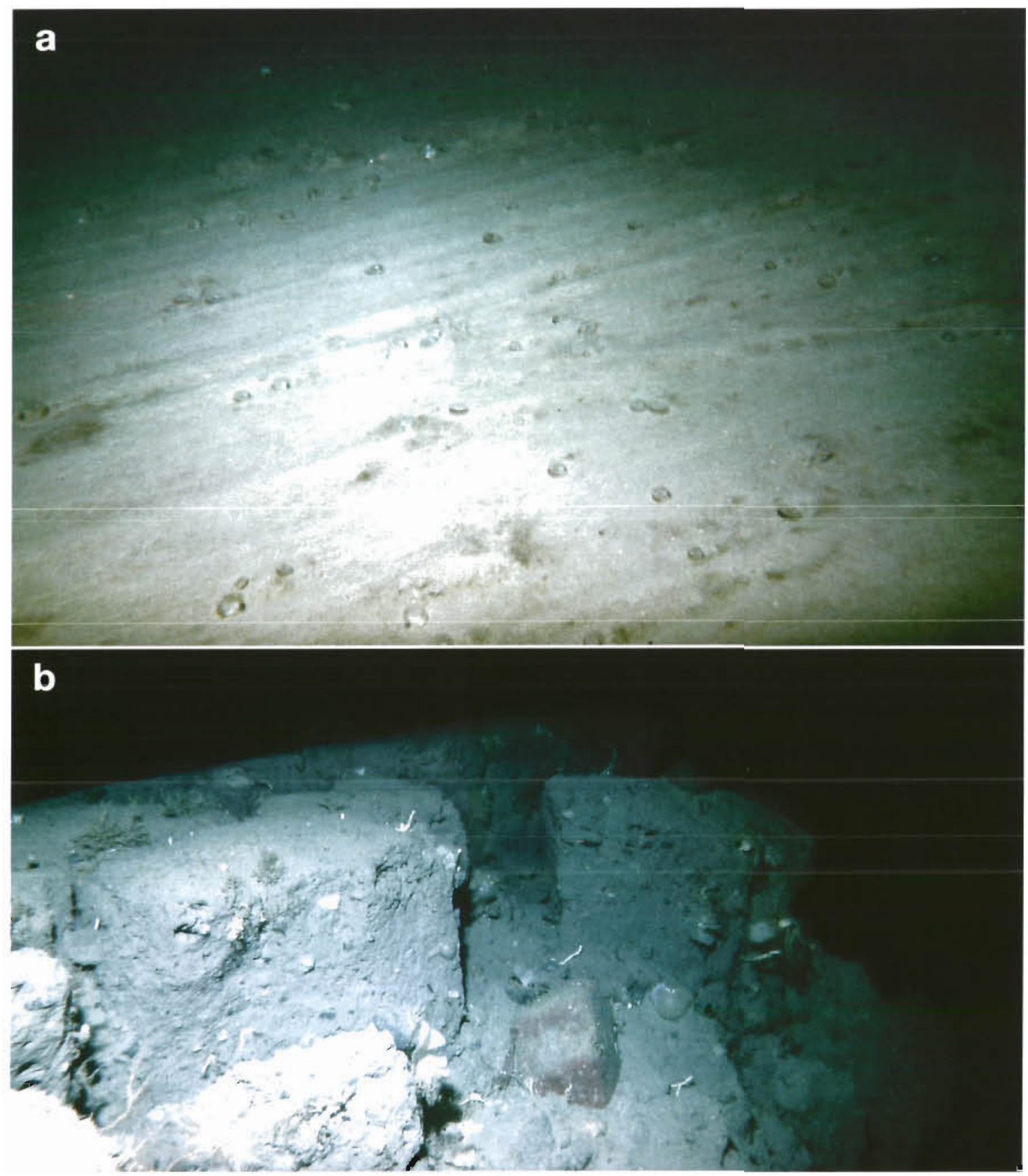

Fig. 2. (a) Sediment surface honed by a horizontally drifting iceberg (off northeast Greenland, $79^{\circ} 11^{\prime} \mathrm{N}, 15^{\circ} 09^{\prime} \mathrm{W}, 51 \mathrm{~m}$ ). First pioneer organism was the motile pectinld blvalve Arctinula greenlandica. Width in the foreground: $\sim 80 \mathrm{~cm}$. (b) Crumbling edge of a gouge mark (Amundsen Sea, $72^{\circ} 50^{\prime} \mathrm{S}, 121^{\circ} 16^{\prime} \mathrm{W}, 384 \mathrm{~m}$ ). Width in the foreground: $100 \mathrm{~cm}$

$82^{\circ} \mathrm{N}, 6^{\circ} \mathrm{W}$ to $17^{\circ} \mathrm{W}$; Fig. $\left.1 \mathrm{~b}\right)$ between 1988 and 1993 Scour marks were found virtually at all depths on the Antarctic shelf $(<500 \mathrm{~m})$, but only above $70 \mathrm{~m}$ in the Arctic. The abundances of all visible organisms were analysed

Results and discussion. Apparent irregularities in the benthic structure were identified as iceberg scour marks under 2 assumptions:
(1) The fine-scale bottom topography revealed an otherwise inexplicable mechanical disturbance, resulting in parallel gouge marks $\leq 1 \mathrm{~m}$ deep (Fig. 2a) or resembling an irregularly ploughed field. Such marks were occasionally bordered by embankments which had begun to crumble (Fig. 2b). Here, as a consequence, all sessile organisms had been eradicated. 
Fig. 3 Underwater video strip transect (Antarctic, Weddell Sea, $71^{\circ} 23^{\prime} \mathrm{S}, 13^{\circ} 57^{\prime} \mathrm{W}$, $307 \mathrm{~m}$. $\mathrm{M}_{1}-\mathrm{M}_{3}$ indicate sections with a mature and diverse species assemblage consisting mainly of sessile suspension feeders; dominant 'sessile/sedentary taxa': Thouarella $\mathrm{sp}$. (Gorgonaria), Abyssocucumis liouvillei (Holothuroidea), Synoicium addreanum (Ascidiacea), Astrotoma agassizii (Ophiuroidea). Cephalodiscidae spp. (Pterobranchia). Most abundant 'motile taxa': Pomachocrinus kerguelensis (Cnnoldea), Asteroidea spp., Cidaridae (Echinoldea). 'Sponges': demospongiae le.g. Stylocordyla borealis, Cinachyra barbata) and hexactinellıda (e.g. Rossella racovitzae. $R$. nuda, $R$. antarctica). S: a recent scour mark which was almost devoid of benthos with the exception of a hexactinellid sponge lying in a small depression. $\mathrm{R}$ : scour mark partly recolonised by motile species (e.g. the crinoid Pomachocrinus kerguelensis) and by the bryozoan Cellaria sp. with a higher cover in most parts of $R$ than in $\mathrm{M}_{1}-\mathrm{M}_{3}$
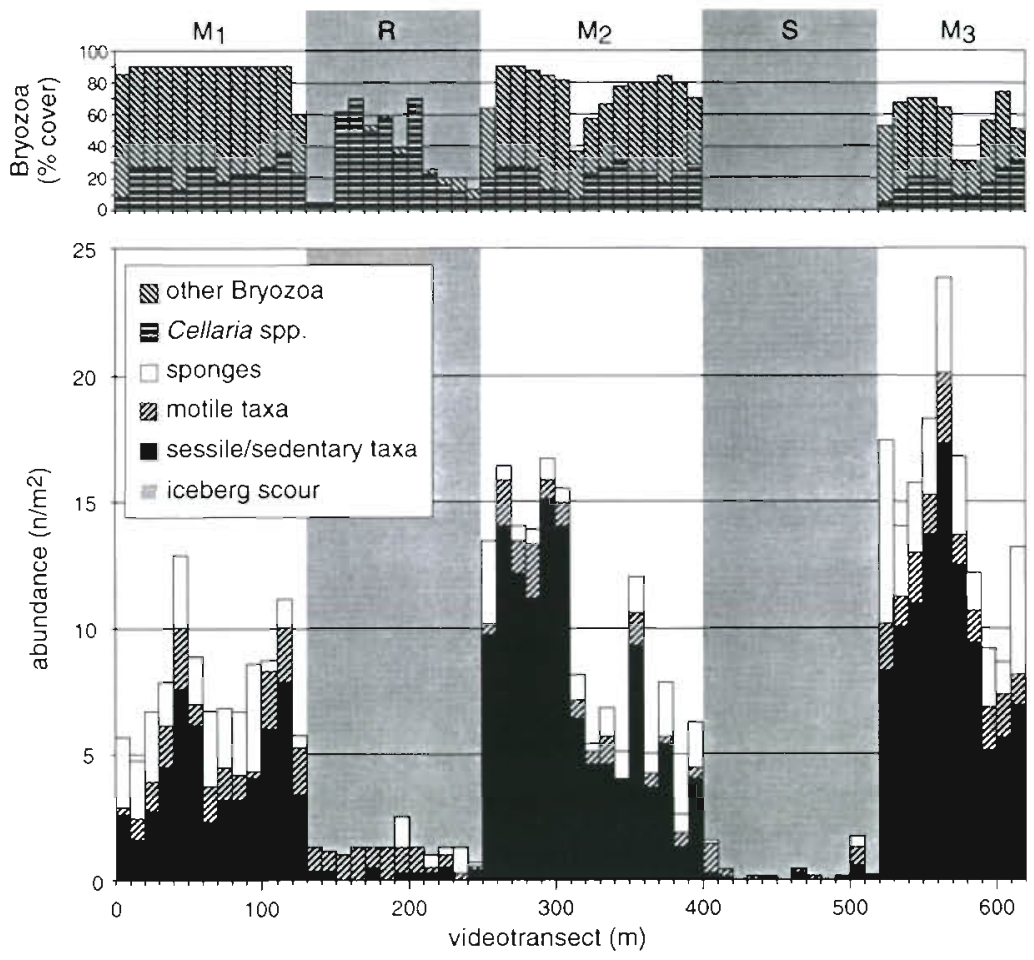

Table 1 Most common pioneer taxa which occur in much higher abundances within (Within d.a.) the disturbed areas than outside (Outside d.a.) (Weddell and Lazarev Seas, Antarctica). For some taxa only the total number of specimens calculated per unit area (= relatıve abundance) within and/or outside the disturbed area and the range of abundance (in parentheses) due to the low abundances. For the other data sets the medians were calculated with the 25 and $75 \%$ percentiles, since the abundances were sufficiently high

\begin{tabular}{|c|c|c|c|}
\hline Taxa & & Within d.a. & Outside d.a. \\
\hline Ophiuroidea sp. & $\begin{array}{l}\text { Median }\left(\mathrm{n} \mathrm{m}^{-2}\right) \\
25 \% \text { percentile }\left(\mathrm{n} \mathrm{m}^{-2}\right) \\
75 \% \text { percentile }\left(\mathrm{n} \mathrm{m}^{-2}\right) \\
\text { Area units investigated }\end{array}$ & $\begin{array}{c}147 \\
103 \\
218 \\
7\left(=5.7 \mathrm{~m}^{2}\right)\end{array}$ & $\begin{aligned} & 59 \\
& 48 \\
& 74 \\
58(= & \left.53.1 \mathrm{~m}^{2}\right)\end{aligned}$ \\
\hline $\begin{array}{l}\text { Stylocordyla borealis } \\
\text { (stalked demosponge) }\end{array}$ & $\begin{array}{l}\text { Rel abundance }\left(\mathrm{n} \mathrm{m}^{-2}\right) \\
\text { Range }\left(\mathrm{n} \mathrm{m}^{-2}\right) \\
\text { Area units investigated }\end{array}$ & $\begin{array}{c}3.9 \\
0.0-14.3 \\
23\left(=12.7 \mathrm{~m}^{2}\right)\end{array}$ & $\begin{array}{c}0.3 \\
0.0-1.8 \\
53\left(=28.4 \mathrm{~m}^{2}\right)\end{array}$ \\
\hline $\begin{array}{l}\text { Latrunculia apıcalls } \\
\text { (demosponge) }\end{array}$ & $\begin{array}{l}\text { Rel abundance }\left(\mathrm{n} \mathrm{m}^{-2}\right) \\
\text { Range }(\mathrm{n} \mathrm{m}) \\
\text { Area units investigated }\end{array}$ & $\begin{array}{c}2.3 \\
0.0-13.3 \\
75\left(=65.9 \mathrm{~m}^{2}\right)\end{array}$ & $\begin{array}{c}0.2 \\
0.0-1.1 \\
77\left(=68.4 \mathrm{~m}^{2}\right)\end{array}$ \\
\hline $\begin{array}{l}\text { Pistasp. } \\
\text { (terebellid polychaete) }\end{array}$ & $\begin{array}{l}\text { Rel. abundance }\left(\mathrm{n} \mathrm{m}^{-2}\right) \\
\text { Range }\left(\mathrm{n} \mathrm{m}^{-2}\right)\end{array}$ & $\begin{array}{c}16.6 \\
4.3-22.1\end{array}$ & $\begin{array}{c}0.03 \\
0.0-3.0\end{array}$ \\
\hline \multirow{3}{*}{$\begin{array}{l}\text { Young specimens of } \\
\text { Synoicium addreanum } \\
\text { (compound ascidian) }\end{array}$} & $\begin{array}{l}\text { Median }\left(\mathrm{n} \mathrm{m}^{-2}\right) \\
25 \% \text { percentile }\left(\mathrm{n} \mathrm{m}^{-2}\right) \\
75 \% \text { percentile } \\
\text { Area units investigated }\end{array}$ & $\begin{aligned} & 19.8 \\
& 11.5 \\
& 22.1 \\
6(= & \left.14.1 \mathrm{~m}^{2}\right)\end{aligned}$ & $\begin{array}{c}- \\
- \\
- \\
- \\
234\left(=684.8 \mathrm{~m}^{2}\right)\end{array}$ \\
\hline & $\begin{array}{l}\text { Rel. abundance }\left(\mathrm{n} \mathrm{m}^{-2}\right) \\
\text { Range }\left(n \mathrm{mi}^{-2}\right)\end{array}$ & $\begin{array}{c}59.7 \\
37.4-82.9\end{array}$ & $\begin{array}{c}1.3 \\
0.0-43.4\end{array}$ \\
\hline & $\begin{array}{l}\text { Median }\left(\mathrm{n} \mathrm{m}^{-2}\right) \\
25 \% \text { percentile }\left(\mathrm{n} \mathrm{m}^{-\hat{2}}\right) \\
75 \% \text { percentile } \\
\text { Area units investigated }\end{array}$ & $\begin{aligned} 61.7 \\
40.4 \\
74.4 \\
6\left(=14.1 \mathrm{~m}^{2}\right)\end{aligned}$ & $\begin{array}{c}- \\
- \\
- \\
234\{=684.8 \mathrm{I}\end{array}$ \\
\hline
\end{tabular}

(2) Areas were classified as having been disturbed by icebergs if an abrupt change in the epibenthic structure could not be explained by other physical or biological processes (Figs. 3 $\& 4 \mathrm{a}-\mathrm{c}$ ). In this case ridges gouged by icebergs had already eroded. An alternative explanation is the vertical settlement of an iceberg caused by a rising and falling tide.

First immigrants after such events were motile organisms such as fish, echinoderms, or bivalves (Fig. 2a). Initial recolonising sessile species were hydrozoans (stylasteridae), sabellid polychaetes, different compound ascidians, and bryozoans (e.g. Camptoplites tricornis, Antarctica). Occasionally some benthic organisms occurred in higher densities within the disturbed areas than outside those areas (Table 1). On the crumbling edges of gouge marks, locally high numbers of sea anemones and 1 demosponge species were observed in the Antarctic, while in the Arctic dense concentrations of an unidentified infaunal polychaete appeared. This mass occurrence of only a very few species can be ex- 
plained by their explosive growth or an especially successful recruitment combined with the lack of competition for space and food.

In Antarctica, dense patches of sponges (e.g. Rossella racovitzae, R. nuda, Scolymastia joubini, Cinachyra barbatal, of which some are extremely slow growing, were frequently observed on small slopes. This can be interpreted as a late recolonisation of exceptionally deep gouge marks, possibly favoured by localised small-scale upwelling. Also, high concentrations of bryozoan debris and sponge spicule mats (Fig. 4b), the possible consequence of iceberg grounding, may constitute the substratum for specifically adapted benthic assemblages.

Quantitative analysis shows the relevance of iceberg scouring for the benthos over a long time span (Table 2). Key organisms in Antarctica, particularly sponges (Dayton 1978), are slow growing (Clarke 1983, Arntz et al. 1994) and other species depend on

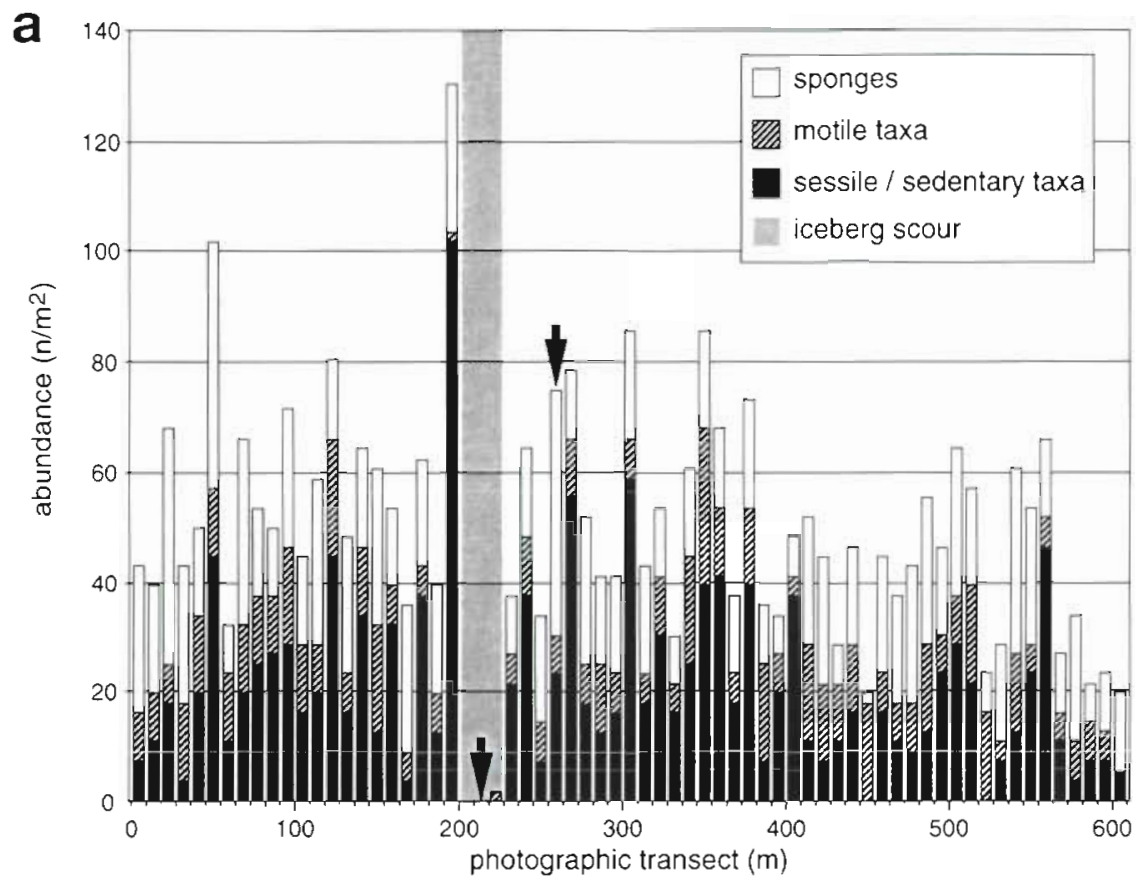

Fig. 4. Rhotographic transect in the Weddell Sea $\left(71^{\circ} 06^{\prime} \mathrm{S}, 11^{\circ} 39^{\prime} \mathrm{W}, 194 \mathrm{~m}\right.$ ). (a) Abundances of macrobenthic organisms along the transect; each bar represents a photograph covering an area of $0.56 \mathrm{~m}^{2}$ Dominant 'sessile/sedentary taxa': Synoicium addreanum, Didemnidae spp. (both Ascidiacea), Ascidiacea sp., Sabellidae sp. (Polychaeta). Most abundant 'motile taxa': Ophiuroidea spp., Notocidaris sp. (Echinoidea), Pomachocrinus kersuclensis (Crinoidea), Pycnogonida spp. 'Sponges' Monosyrnga longispina, Cinachyra barbata, Tedania tantula, which were disrupted by a gouge mark between 200 and $230 \mathrm{~m}$. Arrows indicate position of photographs (b \& c, opposite)
Tabie 2. Absolute and relative abundance of iceberg scours in the Antarctic and Arctic areas of investigation

\begin{tabular}{|c|c|c|}
\hline & Antarctic & Arctic \\
\hline Areas of investigation & $\begin{array}{c}\text { Lazarev Sea } \\
\text { Southeastern Weddell Sea } \\
\text { Amundsen Sea } \\
\text { Bellingshausen Sea }\end{array}$ & $\begin{array}{l}\text { Northeast } \\
\text { Greenland }\end{array}$ \\
\hline Investigated depth range $(\mathrm{m})$ & $100-500$ & $0-70$ \\
\hline Total no of stations investigated & $74^{d}$ & $8^{b}$ \\
\hline Area photographed (m) & 2107 & 0 \\
\hline Area video-taped $\left(\mathrm{m}^{-}\right)$ & 11608 & 4275 \\
\hline Stations with gouge marks & 9 & 4 \\
\hline Total no of gouge marks found & 33 & 22 \\
\hline $\begin{array}{l}\text { Maximum no. of gouge marks } \\
\text { per station }\end{array}$ & 20 & 9 \\
\hline $\begin{array}{l}\text { Estimated maximum age of the } \\
\text { gouge marks (yr) }\end{array}$ & 10 & 5 \\
\hline Disturbed area $\left(\mathrm{m}^{2}\right)$ & 603 & 406 \\
\hline Disturbed area $(\%)$ & 4.4 & 9.5 \\
\hline $\begin{array}{l}\text { Period }(\mathrm{yr}) \text { in which statistically } \\
\text { the area is disturbed once }\end{array}$ & 230 & 53 \\
\hline $\begin{array}{l}30 \text { additional stations below } 500 \\
\text { however, without any indication } \\
17 \text { additional stations below } 70 \\
\text { however, without any indication }\end{array}$ & \multicolumn{2}{|c|}{$\begin{array}{l}17 \text { additional stations below } 70 \mathrm{~m} \text { water depth have been investigated. } \\
\text { however, without any indication of gouge marks }\end{array}$} \\
\hline
\end{tabular}

these (Gutt \& Starmans 1996). Consequently, a mature benthic community will theoretically not become established within a period of $230 \mathrm{yr}$ in the Antarctic and 53 yr in the Arctic area of investigation. However, the grounding of icebergs is patchy with the probability being higher in shallow areas, where the richest species assemblages occur. This may be why we find relatively small glass sponges in areas of the Weddell and Lazarev Seas which are prone to scouring, while much larger individuals of the same species were found in shallow areas of the Ross Sea (Dayton 1972) which are not likely to be affected by icebergs.

Based on this, the question arises whether the perpetual change between such destruction and recolonisation is one of the major causes for the development of the high between-habitat biodiversity, especially in Antarctica (Dayton et al. 1994) 
Fig. 4b. Iceberg gouge mark not yet recolonised. The sediment indicated a mechanical disturbance and consisted of a high proportion of gravel and sponge spicule mats

Fig. 4c. Area adjacent to the gouge mark showing a rich and diverse epibenthic assemblage which totally covered the sediment. Sponges: Rossella racovitzae, Scolymastia joubini, Isodictya sp. Cinachyra barbata, Monosyringa longispina, Tedania tantula; Bryozoa: Cheilostomata sp. (Bryozoa), Cellarinella sp., Austroflustra vulgarns, Reteporella vulgaris; others Cingonaria, Dendrochirotida (Holothuroidea), different compounds Ascidiacea, Anthozoa, Pterobranchia
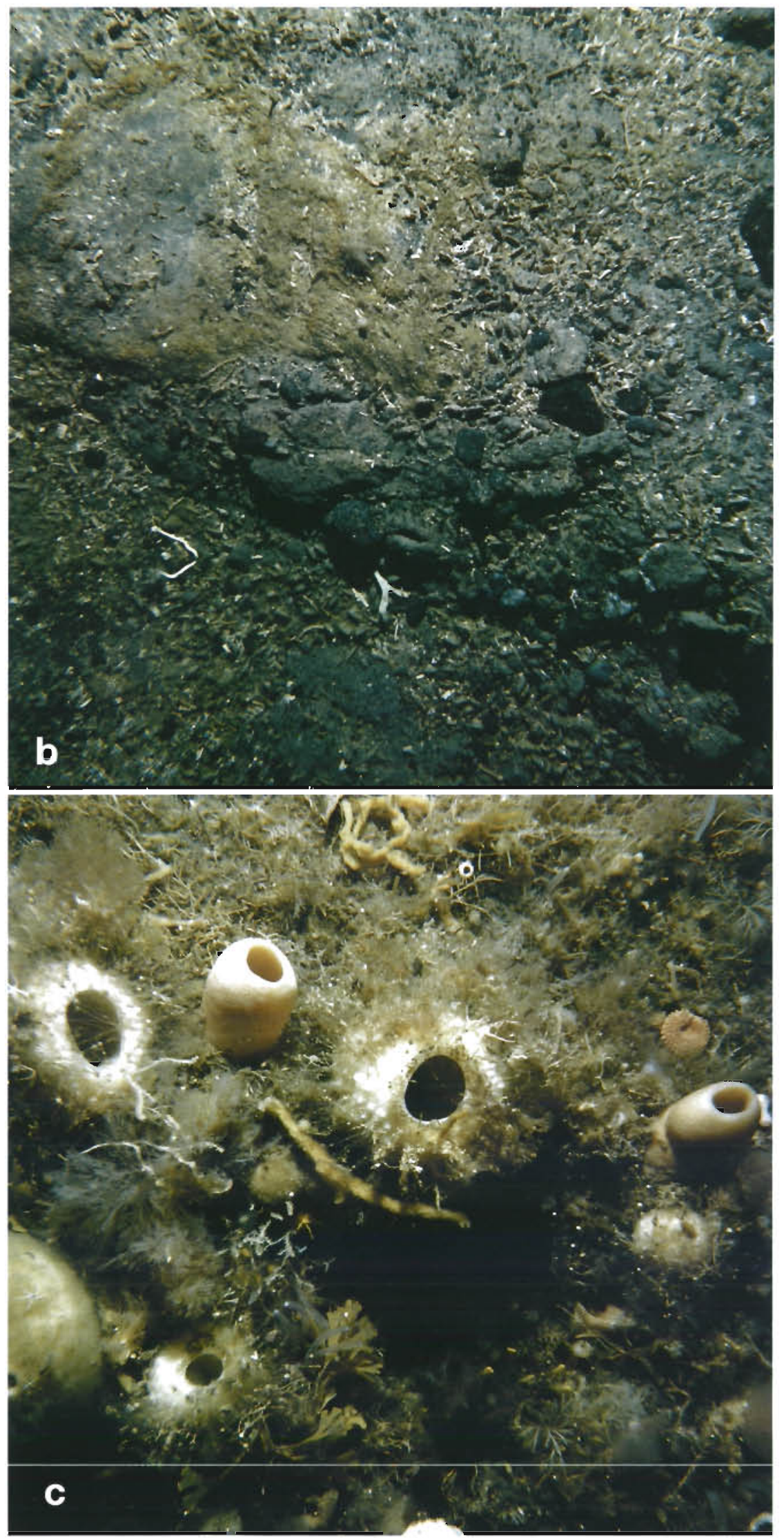
A slight increase in the frequency of iceberg grounding in the Antarctic due to global warming (Houghton et al. 1990) could probably be buffered by the benthic system due to its adaptation to natural catastrophic events. However, we predict that above a certain threshold the benthic resilience will not suffice to prevent serious damage or collapse of the entire community. For the Arctic we also foresee serious but less dramatic consequences because of the lower species number (Dayton et al. 1994) and less complex relationships as well as the lower number of large icebergs (Dayton 1990).

Acknowledgements. Publication No. 1051 of the Alfred Wegener Institute, supported by grant Deutsche Forschungsgemeinschaft (DFG) Gu 390/1

\section{LITERATURE CITED}

Arntz WE, Brey T, Gallardo VA (1994) Antarctic benthos Oceanogr Mar Biol A Rev 32:241-304

Clarke A (1983) Life in cold water the physiological ecology of polar marine ectotherms. Oceanogr Mar Biol A Rev 21: $341-453$

Dayton PK (1972) Toward an understanding of community resilence and the potential effects of enrichments to the benthos at McMurdo Sound, Antarctica. In: Parker BC

This note was submitted to the editor (ed) Proceedings of the Colloquium on Conservation Problems in Antarctica. Allen Press, Kansas, p 81-96

Dayton PK (1978) Observations of growth, dispersal and population dynamics of some sponges in McMurdo Sound, Antarctica. In: Levi C, Boury-Esnault $N$ (eds) Sponge biology. Colloques internationaux du C.N.R.S., No. 291, Paris, p 271-282

Dayton PK (1990) Polar benthos. In: Smith wO (ed) Polar oceanography, part B: chemistry, biology, and geology. Academic Press, London, p 631-685

Dayton PK, Mordida BJ, Bacon F (1994) Polar marine communities. Am Zool 34:90-99

Doake CSM, Vaughan DG (1991) Rapid disintegration of the Wordie Ice Shelf in response to atmospheric warming. Nature 350:328-330

Gammie F (1995) Breakaway iceberg 'due to warming'. Nature 374:108

Gutt J, Starmans A (1996) Macrobenthic structure and biodiversity in the Lazarev Sea (Antarctic): indications for the ecological role of physical parameters and biological interactions. Deep Sea Res (in press)

Houghton JT, Jenkins GJ, Ephraums JJ (1990) Climate change. The IPCC Scientific Assessment. Cambridgo University Press, Cambridge

Lien R, Solheim A, Elverhøi A, Rokoengen K (1989) Iceberg scouring and sea bed morphology on the eastern Weddell Sea shelf. Antarctica. Polar Res 7:43-57

Woodworth-Lynas CMT, Josenhans HW, Barrie JV, Lewris CFM, Parrott DR (1991) The physical processes of seabed disturbance during iceberg grounding and scouring. Cont Shelf Res 11:939-961

Manuscript first received: January 18, 1996 Revised version accepted: April 29, 1996 